\title{
PERBAIKAN KUALITAS CITRA IRIS MATA UNTUK PENGENALAN POLA (BIOMETRIC)
}

\author{
Dadang Heksaputra, Dhina Puspasari Wijaya, Sri Nilawati \\ Jurusan Farmasi, Fakultas Matematika dan Ilmu Pengetahuan Alam, \\ Universitas Islam Indonesia
}

\section{RINGKASAN}

Mata merupakan bagian dari kelima panca indra dari tubuh manusia. Mata mempuyai salah satu bagian disebut iris mata. Iris adalah salah satu organ bagian dalam dari mata terletak di belakang kornea dan di depan lensa. Fungsi utama dari iris mata adalah mengatur ukuran (besarnya) pupil. Banyaknya cahaya masuk ke dalam pupil jatuh pada retina mata dan diatur oleh otototot dalam iris. Iris mata setiap manusia memiliki pola berbeda sehingga dapat digunakan untuk kepentingan identifikasi seseorang. Iris mata manusia bisa menjadi salah satu cara untuk mengidentifikasi atau membuktikan jati diri seseorang, cara ini biasa dikenal dengan biometric.

Aplikasi ini nantinya diharapkan bisa mengidentifikasi bagian dari iris mata serta bentuk pola iris mata seseorang. Sehingga bisa dilanjutkan untuk kepentingan biometrik kedepannya. Metode digunakan adalah metode Histogram Equalizationuntuk perbaikan kualitas citra (image enhacement) dan metode Circle Midpoint Algorithm, daugman's rubber sheet, dan Co-occurence Matrices and Feature untuk mengidentifikasi bentuk pola iris mata.Metode tersebut diharapkan dapat mengidentifikasi iris mata seseorang dan untuk mengetahui apakah dapat mengidentifikasi dengan baik maka sistem akan melalui pengujian data.

Kata kunci: Histogram Equalizatiom, Circle Midpoint Algorithm, daugman's rubber sheet, dan Co-occurence Matrices and Feature, image enhacement, iris, Biometrik.

\section{BAB I \\ PENDAHULUAN}

\subsection{Latar Belakang}

Biometrik adalah karakter-karakter manusia yang dapat digunakan untuk membedakan antara orang yang satu dengan yang lainnya. Salah satu pemanfaatan karakter / organ tubuh pada setiap manusia yang digunakan untuk identifikasi (pengenalan) adalah dengan memanfaatkan wajah. Contoh 
lain dari karakteristik biometrik selain identifikasi wajah adalah ucapan, sidik jari, retina, dan lainnya [5].

Sistem forensik di indonesia telah meniti jejak ke arah bagian tubuh terhadap panca indra salah satunya bola mata. Bola mata terdiri dari beberapa bagian, yaitu sclera, pupil, iris. Terdapat bagian yang menjadi ciri khusus untuk melakukan pengenalan terhadap sistem forensik yang mempunya pola seperti halnya iris mata. Iris mata adalah daerah berbentuk gelang pada mata yang dibatasi oleh pupil dan sclera (bagian puith dari mata). Kelebihan dari iris mata adalah iris mata memiliki tingkat penerimaan kesalahan sangat kecil, karena itu iris mata dapat menjadi alat biometrik aplikasi identifikasi yang baik, dan iris sangat unik serta sulit untuk digandakan. Penelitian ini bertujuan untuk mendeteksi pola iris mata untuk kepentingan biometric.

Fungsi iris memberi warna pada mata. Seperti sidik jari, iris merupakan bagian tubuh manusia yang dapat digunakan sebagai pengenal seseorang dengan tingkat keakuratan yang tinggi. Iris bersifat unik, karena pada satu individu memiliki tekstur iris mata berbeda antara sebelah kanan dan sebelah kirinya. Bahkan pada dua individu kembar identik pun, pola iris juga berbeda. Karena itu, Ciri iris merupakan salah satu ciri yang disimpan pada KTP Elektronik yang akan diimplementasikan secara nasional. Namun demikian, selama ini ekstraksi ciri iris berdasar gelombang singkat (GS), belum menggunakan GS khusus yang menyesuaikan dengan karakteristik sinyal iris maupun berdasar analisis terhadap sifat-sifat GS itu sendir [7].

\subsection{Rumusan Masalah}

Berdasarkan latar belakang masalah telah diuraikan, perumusan masalah dari penelitian ini sebagai berikut:

1. Bagaimana cara mengenali pola iris mata?

2. Bagaimana mengekstraksi pola iris mata?

3. Apakah iris mata kiri dan iris mata kanan berbeda?

4. Apa faktor fitur tekstur paling berpengaruh terhadap tingkat perbedaan iris mata?

5. Bagaimana hasil akhir nilai global dari faktor terhadap tingkat perbedaan iris mata?

\subsection{Batasan Masalah}

Batasan masalah menjadi acuan dalam pengembangan sistem dari penelitian pengenalan pola iris mata ini adalah sebagai berikut :

1. Penelitian ini menggunakan 102 gambar citra mata dari 51 orang, dengan satu orang 2 buah foto iris mata kanan dan mata kiri.

2. Format citra iris mata adalah jpg.

3. Citra yang digunakan untuk sampel didapat dari CASIA database dapat diunduh dari internet (http://biometrics.idealtest.org/). 
4. Data tes citra menggunakan jenis CASIA-Iris-Thousand.

\subsection{Tujuan Penelitian}

Berdasarkan rumusan masalah yang telah diuraikan, tujuan dari penelitian ini adalah mengembangkan sistem yang nantinya dapat mengindentifikasi iris mata seseorang dengan tujuan kepentingan biometrik dengan menggunakan teknik pencitraan.

\subsection{Luaran yang diharapkan}

Luaran yang diharapkan dari pelaksanaan program ini adalah sistem untuk mengindentifikasi iris mata seseorang dengan tujuan kepentingan biometrik dengan menggunakan teknik pencitraan.

\subsection{Manfaat Program}

Penelitian ini diharapkan memiliki manfaat bagi peneliti yaitu peneliti dapat mengaplikasikan secara nyata ilmu yang telah didapatkan selama masa perkuliahan terutama tentang teknik pencitraan. Manfaat bagi peneliti lain yaitu dapat digunakan sebagai tolak ukur untuk penelitian lebih lanjut dan lebih kompleks terkait dengan penggunaan pencitraan dalam kepentingan biometrik.

\subsection{Gambaran singkat dari penulis lain tentang topik yang sama}

Dalam penelitian sebelumnya[12] baru dilaksanakan sampai pengenalan pola tepi iris mata belum dilakukan pengenalan pola pada iris mata, maka dari itu kami mengajukan proposal ini guna pengembangan sistem pengenalan pola iris mata yang ditujukan untuk kepentingan biometrik.

\section{BAB II}

\section{TINJAUAN PUSTAKA}

\subsection{Iris}

Iris mata (selaput pelangi) merupakan daerah berbentuk gelang pada mata yang dibatasi oleh pupil dan sclera (bagian putih dari mata). Struktur permukaan mata disajikan pada Gambar 2.1. Tekstur visual dari iris terbentuk dari proses "chaotic morphogenetic" selama proses perkembangan embrio [8]. Iris mata berfungsi untuk mengendalikan cahaya yang masuk melalui pupil. Ukuran rata-rata diameter iris mata adalah $12 \mathrm{~mm}$ dan ukuran pupil bisa bervariasi dari $10 \%$ sampai $80 \%$ diameter iris mata [3]. Iris berbeda dan unik setiap orang, termasuk yang kembar identik [8]. Salah satu fitur iris yang penting adalah iris mata terletak dibelakang kornea mata sehingga sangat sulit untuk dimodifikasi atau dipalsukan karena beresiko merusak organ mata.

\subsection{Citra}

Sebuah piksel adalah sampel dari pemandangan yang mengandung intensitas citra yang dinyatakan dalam bilangan bulat. Sebuah citra 2Dadalah kumpulan piksel piksel yang disusun dalam larik dua dimensi [1].

\subsection{Pengolahan Citra}

Pengolahan citra adalah pemrosesan citra, khususnya dengan 
menggunakan komputer, menjadi citra yang kualitasnya baik.Umumnya, operasi-operasi pada pengolahan citra diterapkan pada citra bila [11] :

5. Perbaikan atau memodifikasi citra perlu dilakukan untuk meningkatkan kualitas penampakan atau untuk menonjolkan beberapa aspek informasi yang terkandung di dalam citra,

6. elemen di dalam citra perlu dikelompokkan, dicocokkan, atau diukur,

7. sebagian citra perlu digabung dengan bagian citra yang lain.

\subsection{Metode Histogram Equalization} Konsep dasar dari histogram

$$
S_{k}=T\left(r_{k}\right)=(L-1) \sum_{j=0}^{k} P_{r}\left(r_{j}\right)=\frac{L-1}{M N} \sum_{j=0}^{k} n_{j} \quad k=0,1,2, \ldots L-1
$$

equalization adalah dengan menstrecth histogram.

variabel MxN menunjukkan total jumlah piksel, L jumlah tingkat abuabu, dan $P_{r}\left(r_{j}\right)$ jumlah piksel dalam gambar masukan dengan intensitas nilai $r_{j}$. Rentang nilai input dan output abu-abu berada di kisaran $0,1,2, \ldots, \mathrm{L}-$ 1. Kemudian, transformasi histogram

$$
\left[h_{x}\right]=\left[\begin{array}{lll}
1 & 0 & -1 \\
2 & 0 & -2 \\
1 & 0 & -1
\end{array}\right]\left[h_{y}\right]=\left[\begin{array}{ccc}
1 & 2 & 1 \\
0 & 0 & 0 \\
-1 & -2 & -1
\end{array}\right]
$$

vertikal [1]. Dalam kasus ini menggunakan sobel gradien filter.

\subsection{Metode Otsu}

Metode Otsu digunakan untuk segmentasi berdasarkan histogram citra. Metode Otsu ini didasarkan pada histogramnya. Histogram menunjukkan sebaran nilai intensitas dari tiap piksel pada citra dalam 1 dimensi. Jadi sumbu $x$ biasanya menyatakan level intensitas yang berbeda sedangkan sumbu y menyatakan jumlah piksel yang memiliki nilai intensitas tersebut. Pengelompokan ini didasarkan pada nilai ambang batas atau threshold. Nilai threshold ini menjadi objektif atau tujuan dari metode Otsu. Dasar dari metode Otsu adalah perbedaan intensitas dari piksel-piksel yang dipisahkan dalam kelas-kelas tertentu [6].

\subsection{Metode Circle Midpoint Algorithm}

Iris mata berbentuk lingkaran di dalam sclera. Untuk mengambil bagian 
iris mata yang berbentuk lingkaran maka diperlukan pemotong antara iris dan sclera. Pengambilan iris digunakan metode Circle Midpoint. Algoritma Lingkaran Midpoint juga disebut algoritma lingkaran Bressenham. Bressenham mengembangkan generator lingkaran yang cukup efisien. Algoritma yang digunakan membentuk semua titik berdasarkan titik pusat dengan penambahan semua jalur sekeliling lingkaran. Algoritma ini diturunkan dari algoritma Midpoint untuk pembentukan garis. Dalam hal ini hanya diperhatikan bagian $45^{\prime}$ dari suatu lingkaran dan menggunakan CirclePoints untuk menampilkan titik dari seluruh lingkaran [10].

\subsection{Metode daugman's rubber sheet}

Fitur iris yang memuat konten penting yaitu garis-garis, bintik-bintik. Fitur ini yang menjadikan referensi untuk dijadikan tekstur dari iris mata. Ekstraksi fitur menggunakan algoritma yang bermacam-macam. Daugman menyarankan dari diagram kartesian normal ke bentuk transformasi polar yang dipetakan dari piksel di dalam area iris mata ke dalam pasangan koordinat polar [4].

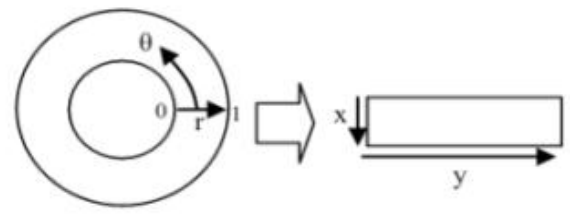

Gambar 2.1 Ilustrasi Daugman Rubber Sheet Model

\subsection{Metode Co-occurence Matrices and Feature}

Tekstur adalah bagian lain dari fitur yang dapat membantu segmentasi gambar ke dalam bagian wilayah yang penting. Matriks intensitas cooccurrence adalah suatu matriks yang menggambarkan frekuensi munculnya pasangan dua piksel dengan intensitas tertentu dalam jarak dan arah tertentu dalam citra. Setelah matriks cooccurrence dibentuk sifat-sifat tekstur ini dapat dihitung berdasarkan matriks tersebut. Fitur yang biasa digunakan dalam analisis tekstur adalah energy, entropy, contrast dan homogeneity. Analisis tekstur dan analisis permukaan dapat digunakan mean dan standar deviasi [1].

1. Contrast/Kontras

$$
\sum_{\mathrm{i} 1} \sum_{\mathrm{i} 2} \mathrm{Pi} 1, \mathrm{i} 2(\mathrm{i} 1-\mathrm{i} 2) 2
$$

2. Homoaeneitv

$$
\sum_{i_{1}} \sum_{i_{2}} \frac{P_{i_{1}}, i_{2}}{1+\left|i_{1}-i_{2}\right|}
$$

3. Energi

$$
\text { Energy }=\Sigma_{i_{1}} \Sigma_{i_{2}} P_{i, j}^{2}
$$

4. Entropy $\Sigma_{i_{1}} \Sigma_{i_{2}} P_{i_{1} i_{2}}\left(-\ln P_{i_{1} i_{2}}\right)$

\subsection{Metode Statistik Pengujian Tabel T}

Pernyataan yang menunjukkan dugaan tentang hubungan antara dua variabel atau lebih. Rumusan hipotesis:

- Tidak ada hubungan antara jumlah fitoplankton dengan hasil tangkapan. Ho: $\rho=0 \mathrm{Ha}: \rho \neq 0$

- Tidak ada pengaruh penambahan jumlah ABK terhadap kuantitas 
hasil tangkapan. $\mathrm{Ho}: \rho=0 \mathrm{Ha}: \rho$ $\neq 0$ [9].

\section{BAB III METODE PENELITIAN}

Berikut ini langkah-langkah untuk menjamin proses perbaikan kualitas citra iris mata untuk pengenalan pola dapat dipertanggungjawabkan secara ilmiah:

\section{a. Pengumpulan Data}

Data adalah foto iris mata dari CASIA database yang digunakan untuk data tesdiunduh dari http://biometrics.idealtest.org/ sebanyak 100 buah. Masukan data berupa data citra iris mata yang didapat dari CASIA database versi Thousand. Citra iris mata berupa citra 2 dimensi dengan ukuran 640 x 480 .

\section{b. Perancangan Sistem}

Pada tahap ini dilakukan perancangan sistem aplikasi yang bertujuan untuk mengembangkan sistem yang nantinya dapat mengindentifikasi iris mata seseorang dengan tujuan kepentingan biometrik dengan menggunakan teknik pencitraan. Citra iris mata akan dilakukan proses perbaikan citra dengan Metode Histogram Equalization dan untuk mendapatkan tekstur pola iris mata dengan menggunakan lima metode diantaraya, Metode Sobel, Metode Otsu, Metode Mid Point, Metode Daughman Rubber Sheet, Metode Matriks Co-Occurence dan Fitur. Setelah dilakukan proses dengan metode tersebut maka akan mendapatkan segmentasi pola iris dan nilai tekstur dari pola iris mata. Pengembangan sistem ini menggunakan bahasa pemrograman Java.

\section{c. Ekstraksi ciri}

Pada tahap ini dilakukan proses segmentasi pada daerah citra bagian iris mata. Segmentasi citra mempunyai peran untuk membagi

suatu citra menjadi wilayah-wilayah yang homogen berdasarkan kriteria keserupaan yang tertentu antara tingkat keabuan suatu piksel dengan tingkat keabuan piksel-piksel tetangganya. Proses segmentasi bertujuan untuk mengidentifikasi beberapa wilayah dalam suatu citra yang memiliki kesamaan corak. Teknik klasterisasi yang ditemui dalam literatur pengenalan pola memiliki kesamaan objek dan dapat diterapkan untuk segmentasi citra. Hasil yang didapat dari segmentasi dilakukan normalisasi dengan metode daughman rubber sheet kemudian dihitung menggunakan fitur tekstur.

\section{d. Uji Sistem}

Pada tahap ini akan menjelaskan dan menggambarkan alur kerja dari sistem yang akan dibuat untuk identifikasi atau bug dari sistem yang dibuat serta sistemerror free.Analisis menggunakan step uji ketepatan segmentasi citra iris matatanpa adanya kelopak mata yang ikut tersegmentasi, uji pola iris mata menggunakan pengujian statistik tabel t. 


\section{BAB IV \\ HASIL DAN PEMBAHASAN}

\subsection{Hasil Pengujian}

Pada penelitian ini dilakukan analisis anatar dua data citra mata dari satu orang yaitu data mata kanan dan mata kiri. Penelitian ini menggunakan sampel dari 51 orang dengan total keseluruhan citra terdapat 102 data. Setelah citra mata berhasil dikenali untuk tujuan segmentasi iris dilakukan langkah pengenalan pola iris dengan menggunakan metode normalisasi daughman rubber sheet model. Setelah berhasil dilakukan normalisasi citra mata dilakukan langkah untuk membaca fitur tekstur dari normalisasi citra iris. Berikut ini pengujian segmentasi dari analisis kebutuhan

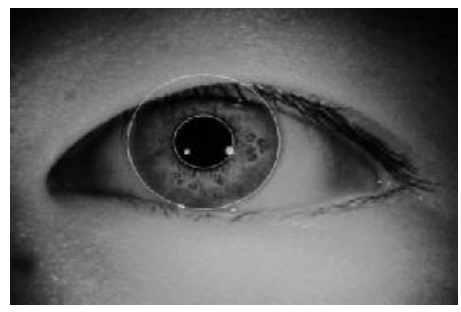

Gambar 4.1 Hasil Identifikasi Daerah Iris Mata

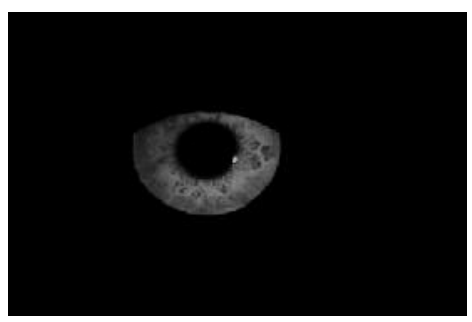

Gambar 4.2 Hasil Segmentasi Kelopak Terpotong Sempurna

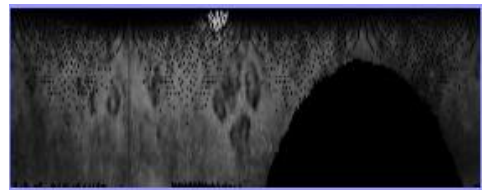

Gambar 4.3 Hasil Pola Iris dari hasil Segmentasi

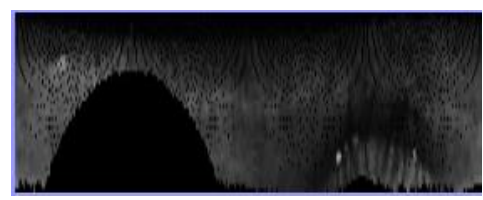

Gambar 4.4 Hasil Identifikasi Daerah Iris Mata

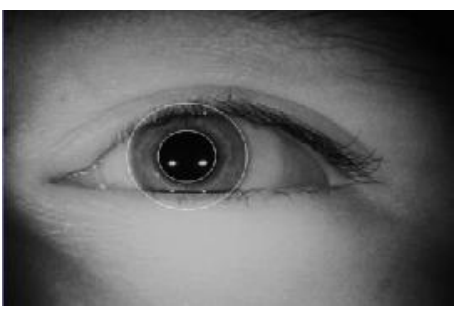

Gambar 4.5 Hasil Segmentasi

Kelopak Terpotong tidak Sempurna

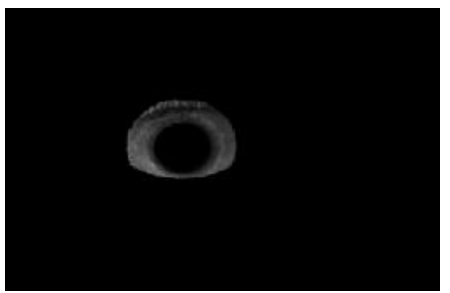

Gambar 4.6 Hasil Pola Iris dari hasil Segmentasi

sistem :

4.2 Pengujian perbedaan pola iris mata kanan dan mata kiri

Pengujian untuk mengetahui perbedaan iris mata kanan dan iris mata kiri menggunakan normalisasi dari representasi bentuk model daughman rubber sheet. Normalisasi dilakukan guna memberikan model relative untuk 
mencegah bila diketahui terdapat nilai jari - jari yang berbeda diantara iris mata kanan dan iris mata kiri. Setelah diujikan terhadap 51 pasang mata dari dataset diperoleh hasil bahwa pola iris mata kanan dan pola iris mata

\begin{tabular}{|c|c|c|c|c|}
\hline \multicolumn{2}{|c|}{\begin{tabular}{l|l|l|l|} 
II S5036L00.jpg_FiturTeksture.txt... $\square$ & 回 & X \\
\end{tabular}} & \multirow{2}{*}{$\begin{array}{l}\text { DS5036R00.jpg_FiturTeksture.tx... } \\
\text { File Edit Format View Help }\end{array}$} & 口回 & $\mathfrak{B}$ \\
\hline File Edit Format View Help & & & & \\
\hline 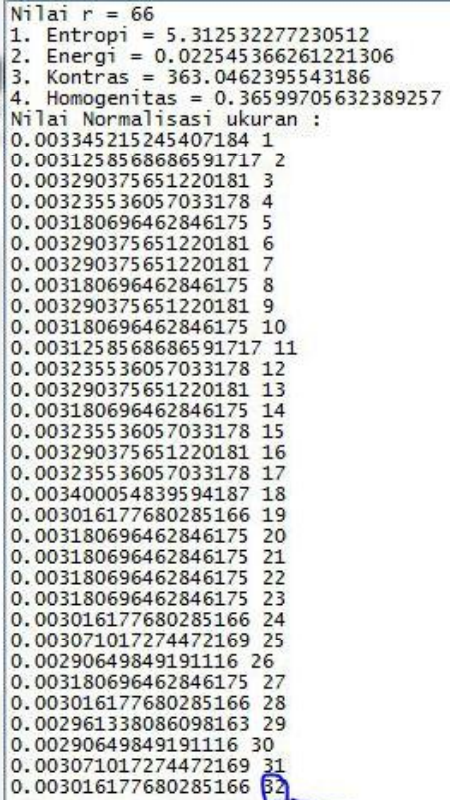 & $\equiv$ & 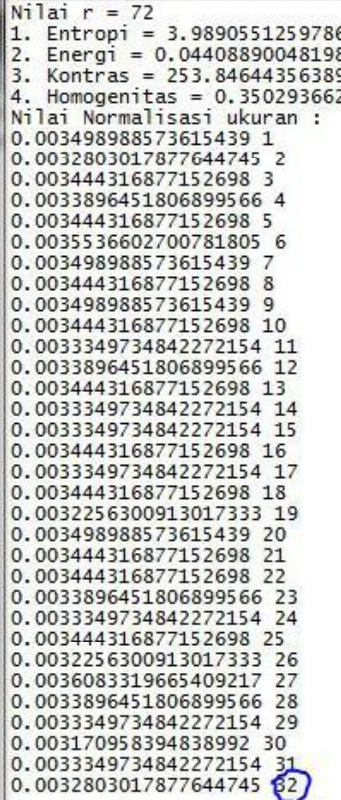 & $\begin{array}{l}6307 \\
3924 \\
9003 \\
203297835\end{array}$ & E \\
\hline
\end{tabular}

Gambar 4.7 Perbandingan Pola Iris Mata Kanan dan Kiri

Berikut ini contoh dari dataset :

Pada gambar 4.7 merupakan hasil perbandingan pola iris mata kanan dan kiri dari dataset seri S5036. Gambar 4.7 menunjukkan terdapat perbedaan jarijari. Iris mata kiri mempunyai jari-jari 66 piksel sedangkan pada iris mata kanan mempunyai jari-jari 72 piksel. Contoh perbedaan dapat diamati dari tanda berwarna biru menunjukkan bahwa sudut 32 , bagian iris mata kiri dan kanan mempunyai nilai yang relatif berbeda, bagian kanan merupakan sudut dari representasi bentuk daughman rubber kiri mempunyai pola hasil normalisasi yang relatif berbeda. Hal ini ditunjukan dari hasil normalisasi tiap sudut dari representasi daughman rubber sheet mempunyai nilai yang berbeda.
File Edit Format View Help

1. Entropi $=3.9890551259786307$

. Energi $=0.04408890048198924$

4. Homogenitas $=0.35029366203297835$

40

(2)

003334973484227215411

(19

00344431687715269822

. 003225630091301733326

003334973484227215429

00317095839483899230

0033349734842272154
0032803017877644745 sheet kemudian bagian kiri adalah hasil nilai normalisasi. Apabila hasil normalisasi tersebut dijumlahkan mempunyai nilai 1 pada bagian iris mata kiri dan bagian iris mata kanan hasil normalisasi mempunyai total nilai 1 , sehingga mempunyai kriteria pembanding yang sama. Setelah didapatkan hasil dari normalisasi kemudian menghitung jarak perbedaan antara iris mata kiri dan iris mata kanan menggunakan Euclidean Distance, serta menghitung korelasi antara iris mata kiri dan iris mata kanan. 
Perbaikan Kualitas Citra Iris Mata.............................Dadang, Dhina, Sri

Tabel 4.1 Tabel Jarak dan Korelasi Iris Mata Kiri dan Kanan

\begin{tabular}{|c|c|c|}
\hline No & Jarak & Korelasi \\
\hline 1 & 0.042407854 & 0.991574299 \\
\hline 2 & 0.142392044 & 0.971026455 \\
\hline 3 & 0.166289735 & 0.938110242 \\
\hline 4 & 0.117019267 & 0.990419782 \\
\hline 5 & 0.066451847 & 0.989048135 \\
\hline 6 & 0.144537457 & 0.833333474 \\
\hline 7 & 0.041161506 & 0.989407568 \\
\hline 8 & 0.078164457 & 0.904588851 \\
\hline 9 & 0.049719047 & 0.994241789 \\
\hline 10 & 0.174256137 & 0.805413416 \\
\hline 11 & 0.158912153 & 0.928051036 \\
\hline 12 & 0.260082606 & 0.896340771 \\
\hline 13 & 0.083023666 & 0.967939474 \\
\hline 14 & 0.29877006 & 0.799715958 \\
\hline 15 & 0.146359361 & 0.94284462 \\
\hline 16 & 0.268317394 & 0.751897614 \\
\hline 17 & 0.309972955 & 0.810497121 \\
\hline 18 & 0.288824648 & 0.419319536 \\
\hline 19 & 0.250376848 & 0.70492666 \\
\hline 20 & 0.192202647 & 0.762384039 \\
\hline 21 & 0.339090173 & 0.037395825 \\
\hline 22 & 0.2043833 & 0.968082421 \\
\hline 23 & 0.035756822 & 0.995950486 \\
\hline 24 & 0.262212993 & 0.932941887 \\
\hline 25 & 0.039418942 & 0.996899809 \\
\hline 26 & 0.082618816 & 0.967081537 \\
\hline 27 & 0.081942589 & 0.964079886 \\
\hline 28 & 0.114393203 & 0.969020788 \\
\hline 29 & 0.228521425 & 0.906997285 \\
\hline 30 & 0.100517667 & 0.938924258 \\
\hline 31 & 0.584687253 & -0.438006322 \\
\hline 32 & 0.023453918 & 0.855472834 \\
\hline 33 & 0.102666784 & 0.968026558 \\
\hline 34 & 0.466291895 & -0.028149069 \\
\hline 35 & 0.073905333 & 0.976532816 \\
\hline 36 & 0.101834378 & 0.964507347 \\
\hline 37 & 0.220245609 & 0.905568872 \\
\hline 38 & 0.241076559 & 0.880246739 \\
\hline 39 & 0.163508296 & 0.960835879 \\
\hline 40 & 0.246189862 & 0.781200039 \\
\hline 41 & 0.153269312 & 0.933532434 \\
\hline 42 & 0.052704685 & 0.993863895 \\
\hline 43 & 0.195491237 & 0.943453324 \\
\hline 44 & 0.084609211 & 0.969678528 \\
\hline 45 & 0.042484673 & 0.992267962 \\
\hline 46 & 0.296471164 & 0.676835752 \\
\hline 47 & 0.079936656 & 0.938194674 \\
\hline 48 & 0.046041427 & 0.994345093 \\
\hline 49 & 0.125132262 & 0.942750344 \\
\hline 50 & 0.138962679 & 0.955845291 \\
\hline 51 & 0.136609016 & 0.92607007 \\
\hline
\end{tabular}


Tabel 4.1 menunjukkan nilai jarak antara iris mata kiri dengan iris mata kanan. Perhitungan jarak dihitung rata-rata (mean) mempunyai nilai 0.163601369 dan nilai standar deviasi sebesar 0.113744785 . Ratarata berfungsi memberi informasi mengenai nilai tengahan dari sebaran data yang ada. Standar deviasi berfungsi memperlihatkan pola sebaran data, gap, dan variasi sebaran antar data. Korelasi positif pada table 4.1 memiliki presentase sebesar $96,08 \%$ sedangkan korelasi negative memiliki presentase $3,92 \%$. Untuk mencari hubungan antara variable mata iris kiri dan mata iris kanan maka dilakukan dengan menghitung korelasi antar variabel yang akan dicari hubungannya. Korelasi merupakan angka yang menunjukkan arah dan kuatnya hubungan antar variable dinyatakan dalam bentuk hubungan positif atau negatif, sedangkan kuatnya hubungan dinyatakan dalam besarnya koefisien korelasi. Berikut ini hasil pengelompokan nilai korelasi dikelompokkan menjadi empat kelompok yaitu tinggi, sedang, redah, dan berkebalikan. Korelasi tinggi dengan nilai batas ambang 0,8 sampai dengan 1 , korelasi sedang mempunyai batas ambang 0,5 sampai dengan 0,8 , korelasi rendah memiliki batas ambang 0,01 sampai dengan 0,5, dan korelasi berkebalikan mempunyai nilai $-0,01$ sampai dengan -1 . Berikut ini hasil dari pengelompokan nilai korelasi :

Berikut ini contoh grafik hasil dataset dari korelasi tinggi :

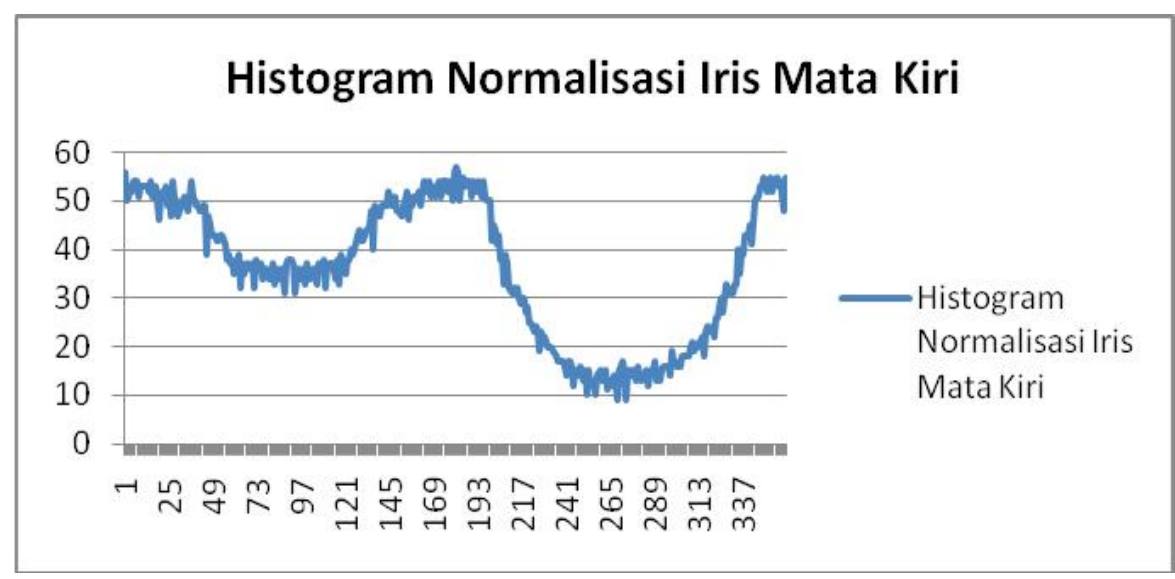

Gambar 4.8 Grafik Histogram Normalisasi Iris Mata Kiri 
Perbaikan Kualitas Citra Iris Mata.............................Dadang, Dhina, Sri

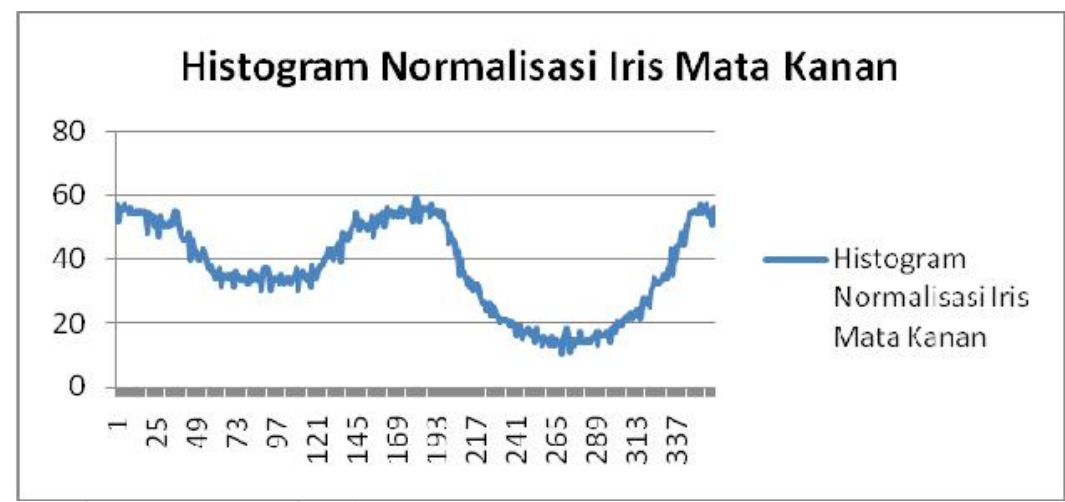

Gambar 4.9 Grafik Histogram Normalisasi Iris Mata Kanan

Pengelompokan korelasi tinggi grafik tersebut korelasi antar variabel terjadi karena antar variabel iris mata mendekati tingkat kemiripan kuat kakiri dan iris mata kanan mempunyai rena koefisien korelasinya tergolong hubungan yang kuat karena nilai koe- tinggi.

fisien korelasi mendekati nilai 1. Pada Berikut ini contoh grafik hasil gambar 4.8 dan gambar 4.9 dilihat dari dataset dari korelasi sedang :

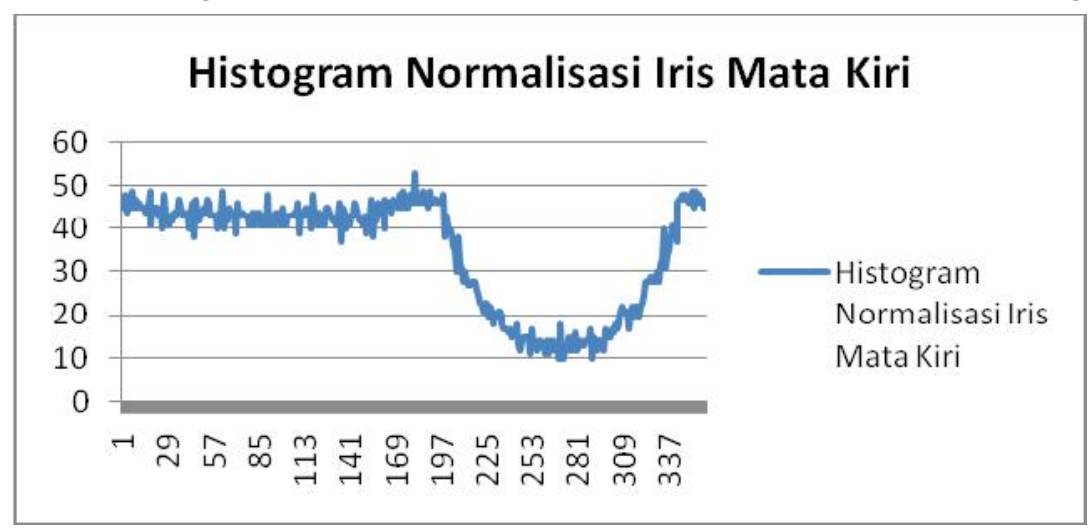

Gambar 4.10 Grafik Histogram Normalisasi Iris Mata Kiri

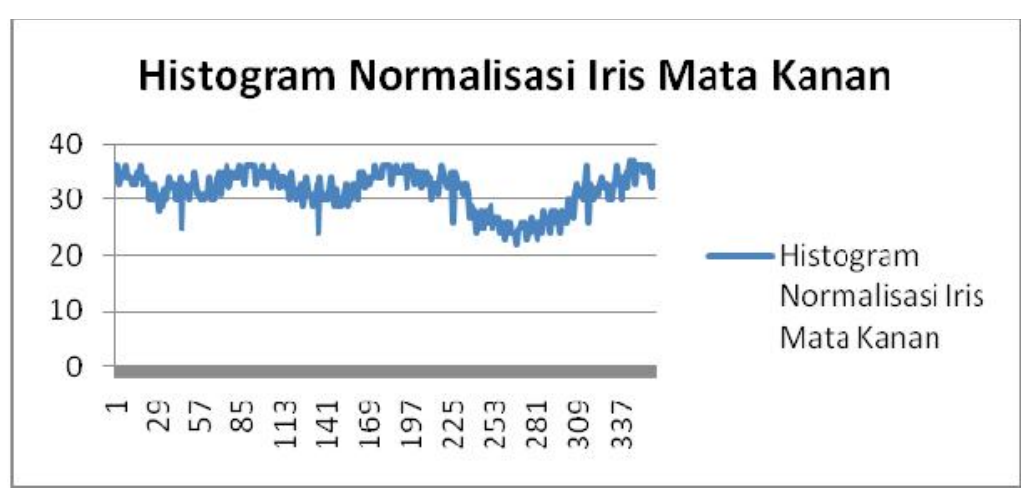

Gambar 4.11 Grafik Histogram Normalisasi Iris Mata Kanan 
Pengelompokan korelasi sedang terjadi karena antar variabel iris mata kiri dan iris mata kanan mempunyai hubungan yang hampir mirip antar variabel. Pada gambar 4.10 dan gambar 4.11 dilihat dari grafik tersebut korelasi antar variabel mendekati tingkat kemiripan hampir mirip karena koefisien korelasinya tergolong sedang.

\subsection{Pengujian Seleksi Fitur}

Pengujian seleksi fitur dilakukan dengan menggunakan alat bantu tools Weka 3.6, berikut ini hasil seleksi fitur Attribute Evaluator ClassifierSubsetEval

\section{Tabel 4.2 Tabel Keakuratan Seleksi Fitur}

\begin{tabular}{|l|l|l|l|}
\hline No & Classifier & ROC Area & Atribut \\
\hline 1 & NaiveBayes & 0.644 & $\begin{array}{l}\text { Entropi, Energi, } \\
\text { Kontras, Homogenitas }\end{array}$ \\
\hline 2 & Bagging & 0.642 & $\begin{array}{l}\text { Entropi, Energi, } \\
\text { Homogenitas }\end{array}$ \\
\hline 3 & AttributeSelectedClassifier & 0.605 & Entropi \\
\hline 4 & ClassificationViaClustering & 0.542 & Kontras, Homogenitas \\
\hline 5 & ClassificationViaRegression & 0.644 & $\begin{array}{l}\text { Entropi, Energi, } \\
\text { Kontras, Homogenitas }\end{array}$ \\
\hline 6 & AdaBoostM1 & 0.579 & Energi \\
\hline 7 & $\begin{array}{l}\text { NaiveBayesMultinomialUpd } \\
\text { ateable }\end{array}$ & 0.603 & Entropi, Kontras \\
\hline 8 & Naïve BayesUpdateable & 0.644 & $\begin{array}{l}\text { Entropi,Energi,Kontras } \\
\text {, Homogenitas }\end{array}$ \\
\hline
\end{tabular}

Tabel 4.2 menunjukan hasil konsistensi dan tingkat keakuratan ROC Area yang sama dan paling tinggi pada tiga buah metode Naïve Bayes, Classification Via Regression, dan Naïve Bayes Updateable dengan nilai 0,644 .

\section{BAB V PENUTUP}

\subsection{Kesimpulan}

Dari hasi pembahasan dari bab sebelumnya maka dapat ditarik kesimpulan sebagai berikut:

1. Mengenali pola iris mata dengan menerapkan metode sobel, otsu, dan circle midpoint sehingga didapatkan hasil segmentasi iris mata.

2. Pola iris mata dapat diekstraksi menggunakan hasil normalisasi dari bentuk representasi model daughman rubber sheet.

3. Hasil analisis menunjukan bahwa terdapat perbedaan antara pola iris mata kiri dan mata kanan pada seseorang.

4. Faktor fitur paling berpengaruh dalam pola iris mata adalah entropi, energi, kontras, dan homogenitas karena perbandingan keakuratan ROC Area dari 3 buah metode menunjukan konsistensi hasil serta paling tinggi. 
5. Hasil akhir nilai global dari faktor berpengaruh terhadap pola iris mata :

a. Entopi : range antara -18.5 sampai dengan 4.3

b. Energi : range antara -0.307 sampai dengan 0.071

c. Kontras : range antara -1405 sampai dengan 328

d. Homogenitas : range antara -1.78 sampai dengan 0.41

\subsection{Saran}

Berdasarkan keterbatasan maka disarankan sebagai berikut:

1. Dapat memilih kernel yang lebih optimal dalam melakukan pemotongan kelopak mata.

2. Menggunakan data citra dari e-KTP Indonesia.

3. Hasil pemotongan tinggi jarijari pada model daughman rubber sheet dapat melakukan pemotongan jari-jari sama antara iris mata kanan dan iris mata kiri.

\section{DAFTAR PUSTAKA}

Ahmad Usman. 2005. Pengolahan Citra Digital. Penerbit:Graha IImu.

C.G.Ravichandran, Magudeeswaran .V. 2012. An Efficient for Contrast Enhancement in Still Image Using Histogram Modification Framework. Journal of Computer Science 8(5): 775-779, 2012. ISSN 1549-3636.

Canny, John. 1986. A Computational Approach to Edge Detection.
IEEE Transaction On Pattern Analysis and Machine Inteligent., vol PAMI -8.

Daugman, J. 2002. How iris recognition works. IEEE Transactions On CircuitsAnd Systems For Video Technology, Vol. 14, No. 1.

Fadlil, Abdul. 2006. Materi Kuliah Machine Learning. Universitas Islam Indonesia: Jurusan Teknik Informatika.

Gonzalez R.C. 1987.Digital Image Processing. Additison - Wesley Publishing Company, USA.

Gusti. 2013, 31 Mei. Iris Mata Potensial Sebagai Tanda Pengenal Paling Akurat.Berita.Tersedia:http:// www.ugm.ac.id/id/berita/7863iris. mata.potensial.sebagai.tanda. pengenal.paling.akurat. diakses pada : 10 April 2014.

Ian T. Young, Jan J. Gerbrands, Lucas J. van Vliet. 1995. Fundamentals of Image Processing. The Netherlands at the Delft University of Technology.

Ledhyane Ika Harlyn, M.Sc. 2012. Uji Hipotesis. Statistik(MAM4137): University of Brawijaya

M.Pauline Baker and Donald Hearn. 1992. Computer graphicsNj. Prentice-Hall.

Munir, Rinaldi. 2004. Pengolahan Citra Digital dengan Pendekatan Algoritmik.Bandung:Informatika.

Wibiyanto dan Muhimmah I. 2012. Segmentasi Iris Mata. Skripsi : Universitas Islam Indonesia. 